\title{
Websites Consulted by Future Primary Level Schoolteachers in France: Differences between Students and Trainees
}

\author{
Sophie Briquet-Duhazé* \\ Education, The Higher School of Teaching and Education (ESPE) and the CIRNEF Laboratory, the University of Rouen, France \\ *Corresponding author: sophie.briquet@univ-rouen.fr
}

Received May 04, 2019; Revised June 14, 2019; Accepted July 02, 2019

\begin{abstract}
Our study investigated how primary school teachers assimilate the results of their internet research and which practical tools they use in the classroom. We wanted to determine what first year primary teachers access in terms of websites and online resources when preparing their French language (as a first language) classes and sequences. We collated 95 questionnaire responses from students preparing for their primary school teaching examination and from trainees who had already passed this examination and are now teaching classes unsupervised throughout the academic year. The results showed both similarities and differences between the cohorts. This information is helping us to build the DIDACFRAN website, the goal of which is to reduce primary school pupil learning difficulties by proposing research results and tools for the class.
\end{abstract}

Keywords: teacher training, hiring teachers, first year teacher

Cite This Article: Sophie Briquet-Duhazé, "Websites Consulted by Future Primary Level Schoolteachers in France: Differences between Students and Trainees.” American Journal of Educational Research, vol. 7, no. 7 (2019): 471-481. doi: 10.12691/education-7-7-6.

\section{Introduction}

DIDACFRAN is a French Normandy region GRR project (Grand Réseau de Recherche Normand, Normandy-based extensive research network) developed by a 17-member team, comprising teacher-researchers (from the fields of Education Sciences, and Language and Psychology Sciences), postgraduates (both Education Sciences and Language Sciences), ESPE ${ }^{1}$ instructors (French), primary school Teachers cum Teacher's Instructors, National Education Inspectors, pedagogical advisors, and research engineers.

Financed by the French region of Normandy, the primary goal of this research is to lower the number of learning difficulties facing primary level pupils and as such it encompasses scientific knowledge, and practical classroom and training tools. A secondary trifold goal is to contribute to the thinking currently being undertaken by education sector professionals, investigate if the results of this research can be applied to teaching practice, and augment teaching training.

In light of the above, the team sought to deliver a custom-made French language pedagogy website that combines research with action steps and that can provide all researchers and sector professionals with access to

1 École Supérieure du Professorat et de l'Education - Higher Academy of Professorship and Education belonging to French universities and tasked with the initial training of primary and secondary schoolteachers, and Principal Education Councilors.
French language research and information sources, five of which include:

- professional research articles;

- research combined with in-classroom application and results;

- classroom tools developed as a result of research results;

- official national education documentation, such as teaching programmes; and,

- scientific and official reports.

This article begins by presenting the research project together with the point-at-issue that is being addressed. The theoretical framework is then outlined along with the methodology underlying the project's survey questionnaire, which was sent to a sample user population comprising intraining primary school level teaching professionals. Finally, the results obtained from the survey responses are detailed and discussed.

\section{French Pedagogy Website Research Project- Challenges and Framework}

The DIDACFRAN GRR French pedagogy research project gathers together researchers and professionals specializing in French language teaching and learning, both written and spoken, who are operating within one or more of the sub-themes, which include: reading, writing, written production, problems, children's literature, allophone students, and, difficulties in any of the above. 
The DIDACFRAN project stems from the ESPE goal to ally research, training, and innovation within education. Initial steps in organizing the website revealed the feasibility of two potential access areas that could house the various topics and drive relevant reader choices, namely 1) French pedagogy sub-domains, and 2) documentation categories. 'French pedagogy sub-domains' would disproportionately address professionals working in the classrooms, whereas 'documentation categories' would disproportionately address the scientific community. Debate and discussion on this point ensued because the DIDACFRAN project seeks to address the needs of both communities.

The working group agreed that the website's home page would include two access avenues. The first was via French pedagogy sub-domain choices, because they are frequently used in documentation research by researchers, trainers, and teachers. The original second avenue, 'document category', was dismissed and replaced by 'actors', which would be both an access avenue and a key word access input. In fact, in several countries it appears that the connection between research results and the development of classroom practice is difficult to implement [1]. The website's URL which will operate from June 2019 is https://didacfran.univ-rouen.fr/, and the University of Rouen will house the site. Appendix 1 displays the website's home page. The top menu bar lists the tabs: Présentation (About); Notre équipe (The team); Textes officiels (Officiels Texts); Recherche (Research), Outils pour la classe (Classroom Tools); Liens Utiles (Links).

The website's main section focuses on French subdomains including:

- conjugation,

- cursive script,

- grammar,

- writing,

- reading,

- children's literature,

- spelling,

- poetry,

- $\quad$ written production, and

- vocabulary.

The website's lower section groups the relevant actors: pupils with special education needs including disabled pupils, allophone pupils, pupils in difficulty, teachers, novice teachers, teacher instructors, parents, and other professionals. Discussions are on-going as to the potential for additional categories.

The website team also agreed the top menu bar should include Textes Officiels (Official Texts) and, in order for the website to address the users' specific needs, both Recherche (Research) and Outils Pour La Classe (Classroom Tools) were included.

As soon as the wireframe was built, the team started working on the scientific research element of the project in order to understand the digital resources that teachers are currently using when preparing their French lessons. Several sub-groups were set up to shed light on the issues from the standpoint of the schoolteacher. Overall, we wanted to determine what primary level teachers do with research results and which practical tools they use in the classroom. For this study our population was made up solely of novice teachers in the process of their initial training at the ESPE. One of our sub-groups reviewed the websites that these novices were using when they were designing their French course content (reading, grammar, spelling) and looked at their preferences in terms both of access (key word search, email, website name, or a combination), and type of site (professional, academic, private teacher sites, public administration sites).

We put forward the hypothesis that novice teachers would more likely turn to websites and teachers' blog sites in order to obtain 'tried-and-tested' teaching content, which corresponds more to accessing research via activity than it does via competences and objectives.

\section{Theoretical Framework}

\subsection{Hiring Primary School Teachers In France}

In France, future teachers are trained in an ESPE (Ecole Supérieure du Professorat et de l'Education). Future teachers belong to several different categories. One feature, Mention 1, concerns the training of first level schoolteachers called 'professeurs des écoles'. They must have completed a master's degree in 2 years (Master 1 and Master 2).

In the Master 1 program, they have the status of Student as they prepare to pass the schoolteacher recruitment competitive examination at the end of the year. This external competition 2 includes written eligibility tests in French and mathematics, and admission tests consisting of two oral examinations. The first is based on a file prepared by the candidate in one of the following subjects: sciences, history-geography, art history, visual arts, music education, or moral and civic education. The second oral test comprises two parts. The first evaluates the skills in Physical Education and Sports (EPS). The second assesses knowledge about the French education system (CSE) [3].

Success at this level allows Trainees to continue their Master studies for a second year at the ESPE, during which time they are paid on a full-time basis while combining their academic studies with part-time teachingwork in one of the Rouen Academy's pre-schools or elementary schools. Trainees work in teams of two with one trainee undertaking three weeks of teaching while the other attends courses at the ESPE and vice versa. Every Friday before the Trainees switch, both work together for that day in the classroom in order to facilitate the teaching handover.

The second sub-group comprises students who are also pursuing their second year in the Master program but who did not pass the Master 1 competitive examination. For the most part these students register to re-sit this examination. They are not allowed to be responsible for teaching classes on an unsupervised basis, so they

2 Arrêté du 19 avril fixant les modalités d’organisation du concours externe, externe spécial, second concours interne, interne spécial et du troisième concours de recrutement de professeurs des écoles paru au JORF $\mathrm{n}^{\circ} 0099 \mathrm{du} 27$ avril 2013. Order of 19 April laying down the organizational arrangements for the external, special external, second internal and special internal competition and the third competition for the recruitment of teachers of schools published in JORF No. 0099 of 27 April 2013. 
undertake two accompanied practical training placements under the supervision of qualified schoolteachers and ESPE instructors. These placements each last three weeks with one taking place in a pre-school and the other in an elementary school.

In Master 2, there are Students who are not yet teachers (as they must still pass the competitive examination) as well as successful (i.e., they have passed the competitive examination) students called Trainees for whom the institution gives a teaching class, while they also pursue the Master 2 program.

\subsection{Difficulties of the Schoolteacher Recruitment Competitive Examination}

In France in order to secure a position as a primary or secondary school level teacher you must hold a master's MEEF diploma as well as passing a competitive examination. While achieving the Master's MEEF diploma is straightforward, the other examination is intensely competitive. For instance, in the Normandy region, some 1,600 examination candidates are seeking to secure just 250 available positions. Candidates prepare for both elements simultaneously. As explained above the competitive exam takes place during the first year of the two-year Master's course. As such, candidate students devote most of their energies to passing the competitive exam. If they fail their year one Masters exams they can retake them in the second year (the 'catching up' exam). The French Ministry for Education requires both before being accepted for a teaching position. Those who fail the competitive examination during year one of the Masters course, retake it in the second year as well as taking the Masters year two exams (except for the dissertation element). If they are successful in their second attempt at the competitive examination then they can repeat the year two Masters course, but with only the outstanding dissertation to complete along with the part-time teaching experience. In contrast, those who pass the year one Master exam as well as the competitive examination continue through to the second year's Master 2 exam, which includes part-time teaching experience. These students must pass all the year two exams including securing approval for the end of course dissertation. Thus, they are successful in year one of the Masters (i.e., both the competitive exam and the year one Masters exam) but end up with more teaching work to do during year two of the Masters.

A reform of the competitive examination is being undertaken because the actual preparation is not the same in the 32 ESPEs operating in France. There will be a continuum of training from Bachelor 2 to Master 1 and the competition will be in Master 2 by 2022.

In terms of Ministry of National Education online resources, it is noteworthy to observe they address the education system, how schools' function, staffing, official documents (https://education.gouv.fr), student teaching resources, and education partners (https://eduscol.gouv.fr). These resources are useful for the oral element of the competitive examination. One site is dedicated to recruitment and explains how to become a teacher (https://devenirenseignant.gouv.fr). However, there are no official online resources that explicitly aim to support preparation for the French competitive examination because the Education Ministry considers the preparation is undertaken within the ESPE during the Master 1 programme.

The project presented in this article aims to support students with the part-time teaching responsibility with selecting adequate online resources. It also aims to help in-service teachers and support their professional development.

\section{Mastery of Language and Digital Resources}

Complete mastery of written and spoken French is an on-going objective of the National Ministry for Education, and of the communities that work towards this major societal issue. This goal has recently been reaffirmed both in the latest French Maternelle (Preschool) programs that have been implemented since September 2015 (BO No. 2, 26 March 2015 - published in the Official Bulletin listing of laws and decrees) and in the French Elémentaire (Elementary School) programs that have been implemented since September 2016 (BO Spécial No. 11, 26 November 2015). Similarly, written and spoken French comprise part of the French Education and Youth Ministry's 'Number 1 domain of the common foundation of knowledge, competences and culture', which came into force in September 2016.

In regional terms, in 2014, 14\% of children living in the Upper Normandy region were identified as being extremely weak readers [3]. At national level, the country's comparative reading comprehension evaluations carried out as part of the international Progress in International Reading Literacy Study (PIRLS) survey, show that French CM1 pupils (9-year olds) obtain generally higher scores than the international average but nonetheless remain below the European average:

With a score of 511 points, France sits above the international average (500 points) but below the European average of 540 points. Since PIRLS first started in 2001, France's overall performance score has fallen at each evaluation point. In 2016 the gap was significant, representing a cumulative fall of 14 points over a period of 15 years. Performance based on comprehension of informational texts has fallen by more than literacy texts (-22 points and -6 points respectively). Complex comprehension performance (interpreting and integrating ideas and information) has had a greater fall than the simpler comprehensive processes (straightforward inference, information retrieval) (-21 points and -8 points respectively). Comparatively few French teachers stated having offered their pupils weekly activities, designed to boost their written comprehension competences. ([4], p. 1)

As the Ministry of Education's DEPP office (Direction de l'évaluation, de la prospective et de la performance Office for evaluating, forecasting and performance) notes in the introduction to its information document of June 2017:

In 2016 roughly one in ten youths attending the Defending Citizenship Day (Journée Défense et Citoyenneté - JDC) experienced problems with reading 
and for half of those the problems were severe. One in ten had barely mastered reading while eight out of ten were capable readers with this number rising to 9 out of 10 for females. Performance levels for boys improve with educational level. Female pupil performance is generally higher than male pupil performance. In mainland France reading problems are more prevalent north of the Loire River. ([3], p. 1)

The ANLCI 3 has observed that $8 \%$ of those living in the Upper Normandy region aged between 18 and 65 are illiterate (the national equivalent is 7\%), (data from the IVQ survey 2011-2012) while 19\% have pronounced, or serious difficulties in at least one of four basic competences (writing, reading, straightforward comprehension, and simple calculations). In terms of the youth cohort, in 2014, 4.5\% were illiterate in Upper Normandy (ANCLI website).

Our theoretical framework draws especially on work by Fluckiger, Bachy \& Daunay [5], which clarifies three elements to take into account as a result of the digital age, namely the burgeoning number of resources, the need to make choices in line with each discipline, and the ceaseless development of content alongside that of new technologies. The authors note that little research exists on professional teaching preparation guides. Following Gueudet and Trouche [6], Fluckiger, Bachy \& Daunay [5] define a resource as:

That which an educator/teacher consults in order to prepare a course: a manual, a website, a preparation sheet, an audio document, a video or photo, a newspaper article, student sheets or an educator's sheet, directly for pupils or for themselves, original and combined content documents...;

That which the educator creates/modifies/adapts to prepare his/her courses can be qualified as a document; we exclude that which is not explicitly set for use in class (educator's general knowledge, general information.... Unless educators designate such material as a resource. (pp. 6-7)

Félix [7] traces the development of the digital training Neopass@tion platform, and notably the processes that transform grass roots teaching situations into training resources. This training platform provides information on an issue we did not take into account here, namely, how to transform educators' resources into documents [8]. Paquin [9] notes that digital pedagogy resources are also used by teachers in minority French-speaking school environments in Canada, firstly because they are free and secondly because teachers have no other resources available. Indeed, it would appear that in several countries, although teachers frequently turned to the computer to prepare their classwork, only a few included computers in the classroom with students.

Finally, in a survey of 907 schoolteachers, Ravestein \& Ladage [10] state:

As part of exercising one's profession, internet-use seems to divide the population as the responses diverged markedly. So, while 33\% propose having children work with the internet, others are not so positive. Similarly, $42 \%$ often draw on pedagogy

3 Agence Nationale de Lutte Contre l'Illettrisme -The National Literacy Agency. resource websites while others state they never or at most rarely check these websites. There is also a marked division when one asks if in the future it will be more effective to communicate directly with students via the internet when shaping their learning. Here $72 \%$ were dubious while the remainder were positive. More than half (54\%) of those surveyed frequently use the internet for information when preparing class lessons compared with $46 \%$ who either rely little on the internet or not at all. (p. 15)

This study is important for us in terms of the comparative insights it can provide between Students and Trainees.

\section{Method}

\subsection{Target Population}

Our target population comprises second-year Students and Trainees enrolled in the University of Rouen (France) Masters Programme 1 MEEF course (Métiers de l'Enseignement, de l'Éducation et de la FormationTeaching, Education and Training Careers); before and after hiring these primary school teachers.

\subsection{Data Collection: Tools and Procedure}

Given that both the students and trainees were very busy with their studies as well as with their respective examinations and classwork preparations, we decided it would be most appropriate to use a questionnaire as our methodology instrument. The questionnaire was built on previously tested interview guidance material. Suitable complementary questions enabled the full landscape to be explored including the websites respondents consulted, the tools they used, the topics they researched, French subdomains, and pupil categories (Appendix 2). On 26 January 2018, the questionnaire was sent to the distribution lists of all the students and trainees enrolled at the three sites within the Rouen Academy (France), namely Évreux, Mont-Saint-Aignan, and Le Havre. We chose mid-academic year to send out the questionnaires so that respondents had already gained a certain amount of experience while not being totally preoccupied with the third term's final evaluation process. On 03 February 2018 we sent out follow-up reminders. We were looking to receive information on digital resource use when novice teachers are preparing their French lessons. We received a total of 95 fully answered and usable returns, 36 of which were filled in by trainees, and 59 that were completed by students.

\section{Results and Discussion}

The results have been used both to understand digital practices when preparing primary level French lessons and to determine if practice differs among trainees (who have passed the professorship examination and who take a class on a part-time basis throughout the academic year) and students (who have not passed the examination and who carry out two three-week accompanied and supervised 
primary level teaching placements during the academic year). To this end we regrouped certain questions (Appendix 2).

\section{Question 1:}

This question aimed to check if most novice in-training teachers use websites when preparing their French lessons.

Table 1. Number of Trainees and Students consulting websites in order to prepare a French lesson

\begin{tabular}{|c|c|c|c|}
\hline & Trainees (36) & Students (59) & Total (95) \\
\hline Yes & 36 & 58 & 94 \\
\hline No & 0 & 1 & 1 \\
\hline
\end{tabular}

Both groups stated they used websites when drawing up their French lesson plans. Neither the different teaching conditions (e.g., between the trainee and the student (who would be teaching under the supervision or guidance of recognized teachers and instructors), nor more significantly, the different effects of internet use on pupil learning appear to influence the practice.

Both groups stated they used websites when drawing up their French lesson plans. Neither the different teaching conditions (e.g., between the trainee and the student (who would be teaching under the supervision or guidance of recognized teachers and instructors), nor more significantly, the different effects of internet use on pupil learning appear to influence the practice.

The goal here was to determine respondents' preferred tools and access points.

Table 2. Respondents' preferred access points and tools

\begin{tabular}{|c|c|c|c|}
\hline & Trainees (36) & Students (59) & $\begin{array}{l}\text { Total } \\
(95)\end{array}$ \\
\hline $\begin{array}{l}\text { Key word } \\
\text { search }\end{array}$ & 33 & 55 & 88 \\
\hline $\begin{array}{l}\text { e-mail } \\
\text { address }\end{array}$ & 0 & 0 & 0 \\
\hline $\begin{array}{l}\text { Website } \\
\text { name }\end{array}$ & 3 & 2 & 5 \\
\hline \multirow[t]{2}{*}{ No response } & 0 & 2 & 2 \\
\hline & & $\begin{array}{l}6 \text { gave two answers: key } \\
\text { word and website name }\end{array}$ & \\
\hline Computer & 36 & 56 & 92 \\
\hline Smartphone & 0 & 1 & 1 \\
\hline Tablet & 0 & 1 & 1 \\
\hline \multirow[t]{2}{*}{ No response } & 0 & 1 & 1 \\
\hline & $\begin{array}{l}1 \text { Trainee added } \\
\text { guidance } \\
\text { manuals as a } \\
\text { second answer } \\
\text { and one Trainee } \\
\text { also added } \\
\text { smartphone as a } \\
\text { second answer }\end{array}$ & $\begin{array}{l}2 \text { Students added they } \\
\text { use a computer as well as } \\
\text { paper; one added } \\
\text { combined computer and } \\
\text { smartphone use; one } \\
\text { Student uses the } \\
\text { computer first and a } \\
\text { tablet second }\end{array}$ & \\
\hline
\end{tabular}

Both groups of participants researched using the key word search technique on a computer.

Questions 3 and 6:

At issue here was which type of website the respondents were using and whether or not they targeted research-based sites. We anticipated multiple responses and as such we included them all as it enabled us to gain a truer picture of internet usage habits.

Table 3. Type of website consulted when preparing French lessons

\begin{tabular}{|l|c|c|c|}
\hline Website Types & $\begin{array}{c}\text { Trainees } \\
(36)\end{array}$ & $\begin{array}{c}\text { Students } \\
(59)\end{array}$ & $\begin{array}{c}\text { Total } \\
(95)\end{array}$ \\
\hline Professional & 6 & 13 & 19 \\
\hline Academic & 20 & 31 & 51 \\
\hline Teacher & 35 & 51 & 86 \\
\hline Ministerial department & 6 & 30 & 36 \\
\hline Research laboratory & 4 & 0 & 4 \\
\hline Other & 0 & 0 & 0 \\
\hline No answer & & 1 & 1 \\
\hline Total respondents' answers & 71 & 126 & 197 \\
\hline
\end{tabular}

Respondents are not consulting research laboratory sites, preferring instead official education sites and teachers' own sites (most professional teacher sites do not require membership). However other more disparate results lead us to believe that certain factors relating specifically to the population's novice status are playing a role. Students rely as heavily on teachers and academic sites as they do on State department sites, whereas trainees overwhelmingly consult teacher and academic sites and devote little time to State department sites. We can thus speculate that students who will be examined on the functioning of the French education system as part of their professorship examination (regulations, laws, operations) more often consult these sites when both preparing their French lessons and keeping up to date with State educationrelated developments.

\section{Question 5:}

This question sought both to verify the responses given to Question 3 and help us understand user habits at the micro-level. Given that the choice of website is manifold, we wanted to determine if any sites are being repeatedly consulted. As before we allowed for and fully counted multiple responses. The top three sites for each category are marked in 'bold'.

The 36 trainees noted 33 different websites while the 59 students cited 19. We may assume from this that being in a position of responsibility (trainee) and taking a class on an independent basis raises the number and frequency of website visits. Students said they visit the éduscol site (National Education Ministry pedagogy website) and edumoov (website set up by teachers who post preparation sheets and teaching sequences, both those free of charge and subject to payment, and where users can also use a tool box to create their own material). It should be noted that trainee respondents most often mentioned both sites, suggesting a level of coherency between the two. Much less cited are teacher sites and official sites (cited fewer than six times). Trainees stated they visit edumoov (14 times), followed by La classe de Mallory (12 times), and Lutin-bazar - a teacher blogsite (10 times). The remainder of the websites were cited fewer than six times and are mainly teacher websites. 
Table 4. Websites visited

\begin{tabular}{|c|c|c|}
\hline & $\begin{array}{c}\text { Trainees } \\
(36)\end{array}$ & $\begin{array}{c}\text { Students } \\
(59)\end{array}$ \\
\hline Education.gouv (official French National Education Department) & & 6 \\
\hline Eduscol (pedagogy site from the French National Education Department) & 10 & 33 \\
\hline Edumoov & 14 & 29 \\
\hline La classe de Mallory & 12 & \\
\hline Lutin bazar & 10 & 4 \\
\hline La main à la pâte & & 4 \\
\hline Bout de gomme & 6 & 6 \\
\hline La classe de Laurène & 6 & \\
\hline Sites des académies & 4 & 2 \\
\hline La classe bleue & 3 & \\
\hline Cenicienta & 3 & \\
\hline Enseigner et apprendre à l'école maternelle & 3 & \\
\hline La classe de Lucia & & 3 \\
\hline Pinterest & & 3 \\
\hline Passéducation & 2 & \\
\hline Maternelle27 & 2 & \\
\hline Dessine-moi une histoire & 2 & \\
\hline Sites enseignants (noms oubliés) & & 2 \\
\hline Ektablog & & 2 \\
\hline Charivari & & 2 \\
\hline Websites cited once & $\begin{array}{l}\text { - La classe de Virginia } \\
\text { - Francetveducation } \\
\text { - Raconte-moi une histoire } \\
\text { - Charivari } \\
\text { - Monécole } \\
\text { - Ecole de crevette } \\
\text { - Val10 } \\
\text { - Ecole des juliettes } \\
\text { - Tanière de Kyban } \\
\text { - Education.gouv } \\
\text { - La main à la pâte } \\
\text { - Le bazar de marie } \\
\text { - Canopé } \\
\text { - Académie de Grenoble } \\
\text { - Materalbum } \\
\text { - Blog JL Guégen } \\
\text { - Nanoug } \\
\text { - Pass éducation } \\
\text { - Orphée école }\end{array}$ & $\begin{array}{l}\text { - La classe de Malory } \\
\text { - Sites recommandés en cours } \\
\text { - Canopé } \\
\text { - CPC Haut-Rhin } \\
\text { - Les coccinelles }\end{array}$ \\
\hline
\end{tabular}

\section{Question 7:}

This question addresses the amount of time students and trainees spent researching and visiting websites. We did not set given time frames or limits, so everyone could express their own experience in line with their own criteria. Some respondents answered in terms of session times. Others indicated the time spent per day or per week and included a wide variety of time periods. We then endeavoured to convert all time spent into number of hours per week.

Table 5. Time spent visiting websites

\begin{tabular}{|c|c|c|c|}
\hline & Trainees (36) & Students (59) & Total (95) \\
\hline 1-2 hr. per week & 3 & 29 & 32 \\
\hline 2-4 hr. per week & 8 & 8 & 16 \\
\hline 4-6 hr. per week & 10 & 5 & 15 \\
\hline 6-8 hr. per week & 2 & 1 & 3 \\
\hline 8-10 hr. per week & 1 & & 1 \\
\hline >10 hr. per week & 2 & & 2 \\
\hline “A great deal” & 8 & 7 & 15 \\
\hline No response & 2 & 9 & 11 \\
\hline & 36 & 59 & 95 \\
\hline
\end{tabular}

Although respondents found it difficult to work out how much time they spent online, differences in behaviour could be attributed to the different nature of the subgroups; one group (trainees) has full teaching responsibilities throughout the academic year and the other (students) has accompanied and supervised classwork sessions comprising short periods of two three-week sessions. Nonetheless, students' class placements are officially evaluated and even if the status with the trainee is different, this element of evaluation does add an extra constraint. As such we cannot make inferences here because increases in time spent carrying out online research is not associated with better teaching performance: internet users know time spent carrying out professional documentation research online is not correlated with enhanced professional teaching skills. Indeed, teachers without professional experience can be confused with the multitude of references offered by the internet.

\section{Question 8:}

This question addresses the issue of French subdomains, which are particularly numerous. Here again the goal is to observe any patterns regarding domains or sub- 
domains that are or are not being researched online. In order to avoid biasing any results we did not detail the sub-domains in the questionnaire. However, to enhance readability we do list them in Table 6 . Several sub-domains were also listed by a single respondent (no restrictions were imposed).

Table 6. French sub-domains that are researched online

\begin{tabular}{|c|c|c|c|}
\hline & Trainees (36) & Students (59) & Total (95) \\
\hline Grammar & 10 & 33 & 43 \\
\hline Conjugation & 2 & 7 & 9 \\
\hline Spelling & 7 & 10 & 17 \\
\hline Dictation & & 1 & 1 \\
\hline Language study & 4 & 1 & 5 \\
\hline Writing & 4 & 1 & 5 \\
\hline Graphism & 3 & & 3 \\
\hline Literature & 6 & 1 & 7 \\
\hline Written expression & 6 & 3 & 9 \\
\hline Oral expression & 4 & 1 & 5 \\
\hline Vocabulary/lexicon & 8 & 4 & 12 \\
\hline Reading & 3 & 10 & 13 \\
\hline Phonology & 5 & 6 & 11 \\
\hline Decoding in reading & 1 & 1 & 2 \\
\hline Encoding & & 1 & 1 \\
\hline Reading comprehension & 5 & 3 & 8 \\
\hline Continuous reading & 4 & & \\
\hline Picture book reading & & 2 & 2 \\
\hline Poetry & 1 & & 1 \\
\hline Fluency & 1 & & 1 \\
\hline All & 5 & 7 & 12 \\
\hline No response & & 13 & 13 \\
\hline
\end{tabular}

Many students on accompanied classroom placement overwhelmingly went online for grammar-related documentation, followed by reading and spelling. Trainees already responsible for teaching classes also researched according to these themes but to a lesser extent. However, they did list a greater number of sub-domains (for example they list Graphism, yet all French schoolchildren undertake a graphism course in pre-school), and we observed they considered all the subdomains to be on an equal footing.

\section{Question 9:}

This question seeks to examine patterns in terms of pupil category and themes, and particularly as regards the types of challenges primary level schoolteachers are facing. As such we made overlapping proposals in order to obtain a finer understanding of the exact category teachers researched online. So, for example we cite 'allophone pupils' as well as 'special educational needs' pupils (clearly 'allophone' pupils also belong to the 'special educational needs' group). Similarly, we proposed a 'pupils with disability' group as well as the 'special educational needs' group and clearly here again there is overlap. We also propose the theme, 'parent' but not 'education partners' (teachers) because research on the parent-teacher relationship in France has shown it is not a collaborative relationship [11].

Table 7. Most researched pupil categories and themes (by frequency)

\begin{tabular}{|c|c|c|}
\hline & $\begin{array}{c}\text { Trainees } \\
\text { (36) }\end{array}$ & $\begin{array}{l}\text { Students } \\
\text { (59) }\end{array}$ \\
\hline Pupils in difficulty & 22 & 35 \\
\hline Allophone pupils & 2 & 10 \\
\hline Pupils with disability & 1 & 10 \\
\hline $\begin{array}{l}\text { Pupils with special } \\
\text { educational needs }\end{array}$ & 10 & 20 \\
\hline Inclusion (education) & 0 & 5 \\
\hline Parents & 2 & 1 \\
\hline $\begin{array}{c}\text { Differentiated } \\
\text { instructions }\end{array}$ & 30 & 42 \\
\hline Other & $\begin{array}{c}\text { - Game-Based } \\
\text { approach }\end{array}$ & $\begin{array}{l}\text { Teaching approach } \\
\text { Summary reports } \\
\text { Teaching content } \\
\text { Guidance examples } \\
\text { Pupil errors } \\
\text { Preparation sheets } \\
\text { Teaching sequences } \\
\text { Greater number of choices }\end{array}$ \\
\hline
\end{tabular}

Both students and trainees most frequently cited Differentiated instruction, followed first by Pupils in difficulty, and then by Pupils with special educational needs, indicating that both groups' research themes and pupil categories are essentially the same. Notwithstanding, we also note that the student group explores all the categories proposed and creates others while the trainee group concentrates primarily on the three cited above (Differentiated instruction, Pupils in difficulty, Pupils with special educational needs).

\section{Question 10:}

This is a key question in terms of the DIDACFRAN website, namely because it addresses the issue of being able to find everything that is needed, irrespective of actor identity (student/trainee), when conducting online research into French class preparation.

Eleven out of 26 trainees answered 'yes' to this question, one did not respond and 24 said resources were missing. Of note is the fact that four trainees replied 'Yes, but' and listed their reservations. Below are the elements that they perceived to be missing when they conducted their research:

- the internet is enormous and needs reference sites containing the essential information and documentation;

- ideas, and clearer direction on differentiated instruction: quoted 4 times;

- $\quad$ support for pupils in difficulty;

- a general website containing a beginner's toolbox;

- lack of concrete elements to build written learning sequences;

- interesting documents but hard to put into classroom practice;

- problem examples (grammar and conjugation);

- class exercises adapted to pupil difficulty level; 
- a wealth of resources available on unwieldy academic websites resulting in time lost: quoted 2 times;

- $\quad$ time lost through ineffective key words;

- scarcity of activities for migrating pre-schoolers' handwriting (from print to cursive); 4

- cursive handwriting activities;

- reading progression and written production;

- class preparation sheets;

- free-of-charge and easy-to-apply resources;

- links between teaching research and concrete teaching examples;

- assistance with sequence building;

- materials have to be made individually such as 'picture books';

- reading study ideas such as reading lists, references, reading sheets;

- an available bank of theory-practice sequences that can be implemented quickly and effectively; and,

- examples of different approaches to learning literature.

Twenty out of 59 students replied 'Yes' to this question, 18 did not reply, and 24 stated that resources were lacking, compared to the four trainees who had replied 'Yes, but' and detailed what was lacking. Below is a list of things 15 students found lacking when conducting their research:

- ideas and clearer direction for differentiated instruction: quoted 4 times;

- assisting pupils in difficulty: quoted 3 times;

- preparation sheets;

- sequencing;

- teacher guides;

- summary reports;

- how to organize sessions;

- exercises; and,

- pupil errors.

Trainees appeared to identify a greater number of research deficits and the deficits that they identified were clustered around assistance and support avenues. More students are generally satisfied and when they did identify lacunae they tended to be more in terms of ready-to-use class sessions and sequences. In both cases some respondents stated they relied on the teacher's guidance manual when they couldn't find anything through their website searches. Manuals are thus a secondary resource and used as a complement to other tools.

\section{Conclusions}

The DIDACFRAN website is currently under construction and its aim is to make the right resources available from both research and practical domains within French language and literature learning. The website designers are looking to meet the expectations and needs of both in-training and in-practice teachers, as well as teaching instructors as they seek documents to help them take classes and/or learn about the latest developments and research in any of the various French language and literature sub-domains. As such our own web-creation

4 French children between the ages of 3 and 5 learn to write in capitalized print form. They then progress to cursive writing. French schoolchildren do not learn lower case print writing. team comprises members from both areas (with experience in both fields either at the same time or contemporaneously). All the resources have been catalogued and are in the process of being systematically uploaded onto the site that is scheduled to be operational in June 2019. In order to optimise this website's effectiveness, we have analysed survey data based on questionnaire responses and interviews in a bid to understand teachers' digital resource needs as well as their online histories and experiences when they prepare their French language teaching classes.

This article in particular summarises website use and practices by novice in-training teachers (both those responsible for teaching primary school classes and those undergoing teaching placements in the presence of qualified teachers). We noted both similarities and differences between these teacher categories depending on the question, with similarities evident as regards recourse to websites, key-word searches, themes, and pupil categories. While scientific and teacher sites are heavily relied upon by both students and trainees, only students visited the Education Ministry sites. Trainees visit sites relating to all the French sub-domains and this may be due to their novice status as well as not having passed the competitive professorship examination. This would suggest that they readily associate class session preparation with the mastering of official texts and an understanding of the education system, which are required elements when hiring after successfully completing the schoolteacher recruitment competitive examination.

\section{Acknowledgements}

This work was carried out with support from the "Grands Réseaux de Recherche de Haute-Normandie", France (GRR CSN Didacfran). Article translated by Elma Dobson, funded by the IRIHS and CIRNEF, Normandy University of Rouen, France.

\section{References}

[1] Briquet-Duhazé, S. \& Turcotte, C. (2018). De la recherche en lecture-écriture à la pratique. Éditions ISTE : Londres.

Briquet-Duhazé S., Turcotte C. (2019) (coord.). From ReadingWriting Research to Practice. London/Hoboken: ISTE/Wiley, New Jersey, USA.

[2] Briquet-Duhazé, S. (2017). Un entraînement à l'oral du concours de professeur des écoles en France. Une transposition des ateliers en maternelle. Annales de l'Université de Craiova, Série psychologie-pédagogie, 35-36, 87-100.

[3] Arzoumanian, P., Chabanon, L., Rivière, J. P., De La Haye, F., \& Gombert, J. E. (2017). Journée Défense et Citoyenneté 2016: environ un jeune Français sur dix en difficulté de lecture. Note d'information de la DEPP, 17.17.

[4] Colman, M. \& Le Cam, M., (2017). PIRLS 2016: évaluation internationale des élèves de CM1 en compréhension à l'écrit. Évolution des performances sur quinze ans. Note d'information de la DEPP, 17.24

[5] Fluckiger, C., Bachy, S. \& Daunay, B. (2014). Les enseignants face aux ressources numériques. Une recherche didactique. Journées Communication et Apprentissage Instrumentés en Réseau (JOCAIR), Paris, France.

[6] Gueudet, G. \& Trouche, L. (2010).Ressources en ligne et travail collectif enseignant: accompagner les évolutions de pratiques. 
Actes du congrès de l'AREF, Genève, Suisse. (Online resources and group teacher work: supporting changing practices. Actes du congrès de l'AREF, Geneva, Switzerland).

[7] Felix, C. (2014). De l'intervention-recherche à la production de ressources: quelle didactisation de l'activité pour la formation des enseignants? Recherche et Formation, 75, 51-64.

[8] Aldon, G., Front, M. \& Gardes, M. L. (2017). Des intentions de l'auteur aux usages en classe, première réflexion sur la cohérence des usages d'une ressource. Éducation et Didactique, 3(11), 9-30.

[9] Paquin, M. (2012). Les politiques sur l'intégration des TIC au
Canada et l'utilisation des ressources pédagogiques numériques chez les enseignants francophones: un constat de doubles inégalités. In P. Charland, C. Daviau, A. Simbagoye \& S. Cyr (dir.), Écoles en mouvements et réformes: enjeux, défis et perspectives (p. 133-144). Bruxelles, De Boeck.

[10] Ravestein, J. \& Ladage, C. (2014). Ordinateurs et Internet à l'école élémentaire française. Usages déclarés de 907 professeurs d'école. Éducation et Didactique, 3(8), 9-22.

[11] Feyfant, A. (2015). Co-éducation : quelle place pour les parents ? Dossiers de Veille de l'IFE, 98, 1-24.

\section{Appendices}

\section{Appendix 1: Website DIDACFRAN}

Didacfran Présentation Notre équipe Textes officiels Recherche Outils pour la classe Liens utiles

Fonctionne en mode maintenance.
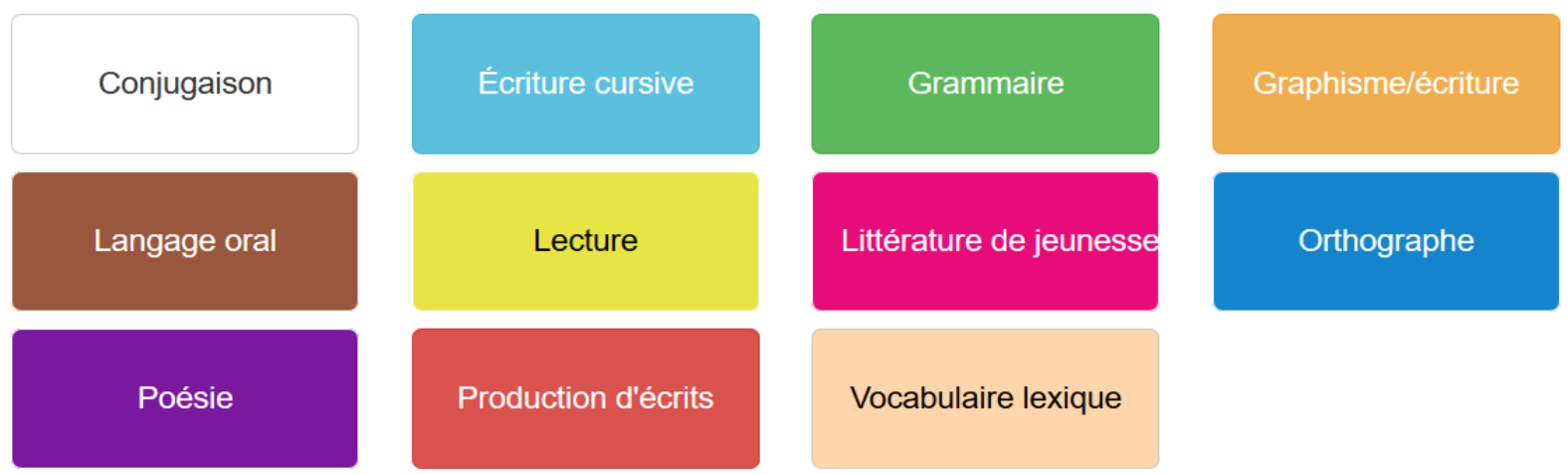

Littérature de jeunesse

Vocabulaire lexique

\section{Les acteurs}
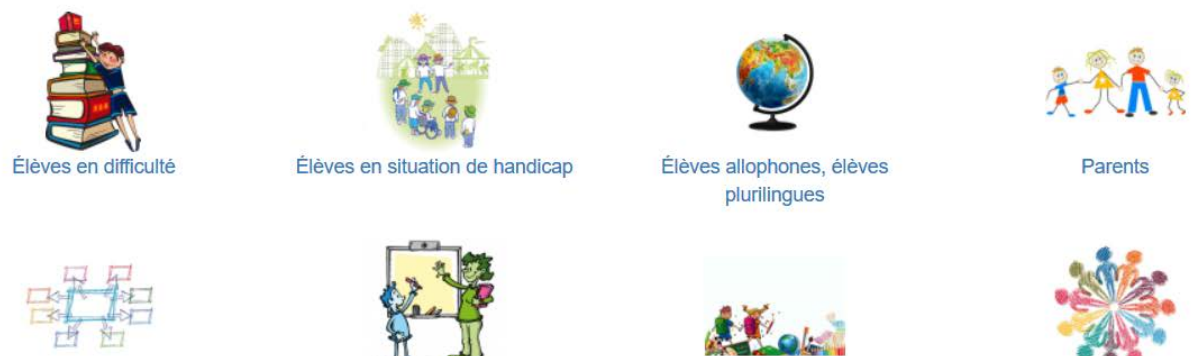

Formateurs
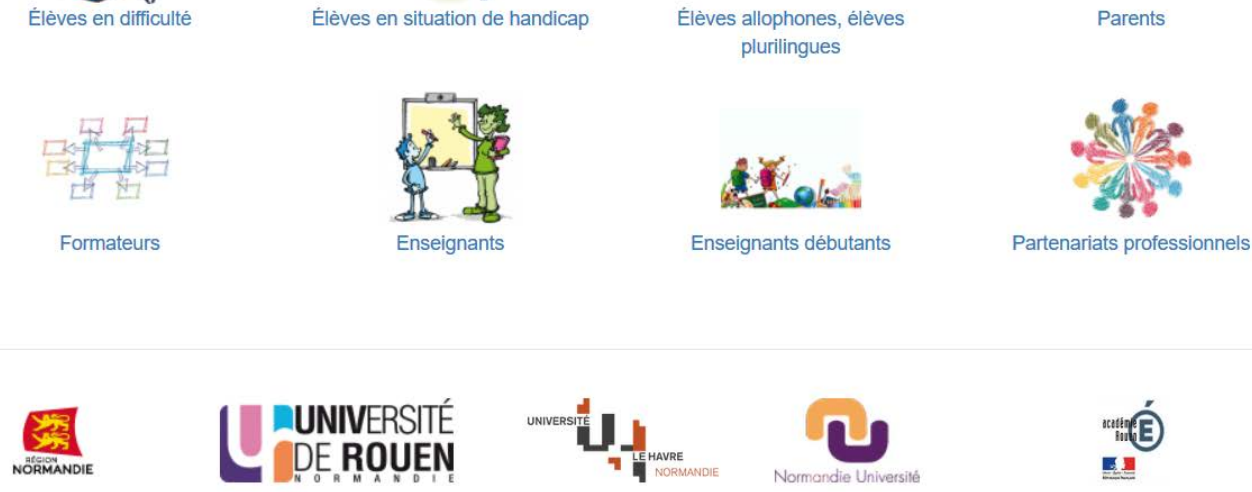


\section{Appendix 2: questionnaires}

\section{Questionnaire anonyme Stagiaire en alternance M2 PE Site en didactique du français}

1. Consultez-vous des sites lorsque vous souhaitez réaliser des séances de français (lecture, grammaire, orthographe...) durant vos périodes dans votre classe?

$$
\text { Non } \square \quad \text { Oui } \square
$$

2. Quelle entrée choisissez-vous de préférence :
$\square$ Mots-clés
$\square$ Adresse-mail
$\square$ Intitulé du site

3. Les sites de français que vous consultez, sont-ils plutôt :
$\square$ Professionnel
$\square$ Académique
$\square$ Privé (réalisé par des enseignants)
$\square$ Ministériel
$\square$ Autre (précisez)

4. Qu’utilisez-vous de préférence : ordinateur, téléphone, tablette... pour concevoir vos séances de français ?

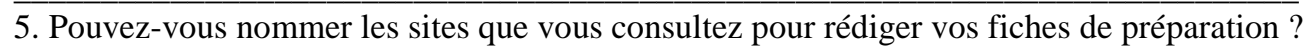

6. Allez-vous sur les sites des laboratoires de recherche?

Non $\square \quad$ Oui $\square$

7. Combien de temps passez-vous à chercher, à lire, à choisir des séances, des exercices ?

8. Pour quels sous-domaines du français cherchez-vous sur des sites?

9. Cherchez-vous des documents en didactique du français concernant :

- $\quad \square$ les élèves en difficulté

- $\quad \square$ les élèves allophones

- $\quad \square$ les élèves en situation de handicap

- $\quad \square$ les élèves à besoins éducatifs particuliers

- $\quad \square$ l'inclusion scolaire

- $\square$ Les parents

- $\quad \square$ La différenciation pédagogique

- $\quad \square$ Autre (préciser) :

10. Trouvez-vous ce que vous souhaitez, que vous manque-t-il ?

\section{Questionnaire anonyme Étudiants M2 PE Site en didactique du français}

1. Consultez-vous des sites lorsque vous souhaitez réaliser des séances de français (lecture, grammaire, orthographe...) durant votre stage de pratique accompagnée ?
Non $\square$
Oui $\square$

2. Quelle entrée choisissez-vous de préférence :
$\square$ Mots-clés
$\square$ Adresse-mail
$\square$ Intitulé du site

3. Les sites de français que vous consultez, sont-ils plutôt :
$\square$ Professionnel
$\square$ Académique
$\square$ Autre (précisez)
$\square$ Privé (réalisé par des enseignants)
$\square$ Ministériel

4. Qu'utilisez-vous de préférence : ordinateur, téléphone, tablette... pour concevoir vos séances de français ?

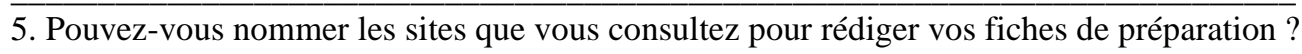

\section{Allez-vous sur les sites des laboratoires de recherche?}

Non $\square \quad$ Oui $\square$

7. Combien de temps passez-vous à chercher, à lire, à choisir des séances, des exercices ?

8. Pour quels sous-domaines du français cherchez-vous sur des sites?

9. Cherchez-vous des documents en didactique du français concernant :

- $\square$ les élèves en difficulté

- $\quad \square$ les élèves allophones

- $\quad \square$ les élèves en situation de handicap

- $\quad \square$ les élèves à besoins éducatifs particuliers

- $\quad \square$ l'inclusion scolaire 
- $\quad \square$ Les parents

- $\quad \square$ La différenciation pédagogique

- $\quad \square$ Autre (préciser) :

10. Trouvez-vous ce que vous souhaitez, que vous manque-t-il ?

(c) ()

(C) The Author(s) 2019. This article is an open access article distributed under the terms and conditions of the Creative Commons Attribution (CC BY) license (http://creativecommons.org/licenses/by/4.0/). 